\title{
GEJALA KLINIS SEBAGAI PREDIKTOR PADA KARSINOMA SEL BASAL
}

\author{
*Ratih Pramuningtyas, **Prasetyadi Mawardi, \\ *Fakultas Kedokteran Universitas Muhammadiyah Surakarta \\ **Bagian Ilmu Kesehatan Kulit dan Kelamin, RS Dr. Moewardi Surakarta, Fakultas Kedokteran Universitas sebelas Maret \\ Surakarta \\ Correspondence to : dr. Ratih Pramuningtyas \\ Email : Pramuningtyas dr@yahoo.com
}

\begin{abstract}
Basal Cell Carcinoma (BCC) incidence is $75 \%$ of all skin cancers. BCC rarely causing mortality, but morbidity is high. Clinical diagnostic is the early detection of BCC suspicion, therefore, we required specific criteria that help to establish the clinical diagnosis. The objective of this study was to know the clinical sign as a predictor of basal cell carcinoma. Ten patients with skin tumors who came to dermatovenereological department of Dr. Moewardi hospital were included in this study. Clinical diagnosis using clinical criteria from keratinocyte carcinoma in A Cancer Journal For Clinicians in 2011 (Teleangiectasion, raise border, erythematous with bleeding, pigmentation, translucent appearance, and scarlike appearance) was used as reference of clinical diagnostic criteria. Histopathological examination was performed as a gold standard. All 10 subjects had histopathological finding consistent to BCC. The clinical examination like pigmentation were found in all subjects while teleangiectasia, raise border, erythema with bleeding were found on 9 subject. Translucent appearance was found on 6 subjects. While scarlike appearance was absent in all subjects. The criteria from keratinocyte carcinoma in A Cancer Journal For Clinicians in 2011 can be used to diagnosed BCC clinically
\end{abstract}

Keywords : Basal cell carcinoma, Clinical Diagnostic Criteria

\section{PENDAHULUAN}

Karsinoma Sel Basal (KSB) adalah neoplasma ganas yang berasal dari sel non keratinisasi yang berasal dari lapisan basal epidermis (Carucci et al, 2008). Merupakan tumor kulit yang paling sering ditemukan pada populasi kulit putih (Bakis et al, 2004). KSB menyumbang sekitar $75 \%$ dari semua kanker kulit. Angka kematiannya sangat rendah, tetapi KSB kadang kala tumbuh secara agresif menyebabkan destruksi jaringan yang luas (Tilli et al, 2005). Levi et al melaporkan bahwa insidensi KSB di Swiss Canton of Vaud anatar tahun 1976-1998 adalah 75.1 pada 100.000 laki-laki dan 66.1 pada 100.000 perempuan. Insiden KSB meningkat sesuai usia dan lebih banyak terjadi pada pria dibandingkan pada wanita, meskipun dengan adanya perubahan pola hidup perbedaan jenis kelamin menjadi kurang bermaknan (Christenson et al, 2005).

Basalioma merupakan karsinoma lowgrade dimana secara klinis sering ditemukan pada area yang terpapar sinar matahari dan tidak menimbulkan masalah dalam diagnosis klinis. Namun sejak penampakan KSB bervariasi sesuai dengan pola histologisnya, dan lokasinya kadang tidak seperti biasa, diagnosis tidak selalu tercapai secara klinis (Solano et al, 2008). KSB kadang kala sulit untuk dibedakan dengan lesi epitelial jinak maupun ganas (Bakis et al, 2004). Diagnosis banding antara basal sel karsinoma dengan lesi kulit yang lain sangatlah penting, dan dapat berakibat morbiditas yang serius jika tumor tidak terdiagnosa (Altamura et al, 2010). Variabilitas dalam presentasi klinis dan persamaan dengan jenis kanker kulit non-melanoma dan dermatosis papulosquamosa pada beberapa pasien mungkin membuat diagnosis sulit ditegakkan bahkan untuk dermatologis yang berpengalaman (Kuzmina et $a l$, 2005). Oleh karena itu dibutuhkan metode diagnosis yang objektif dan non infasif untuk screening lesi yang dicurigai ganas.

Beberapa metode diagnosis awal kecurigaan KSB menggunakan cara non invasif telah dilaporkan. Diantaranya menggunakan Skin self- 
Examinaton Performance, Color and histogram Measure untuk mendeteksi area semitranslusen, electric Impedance Measurement, Transepidermal water loss (TEWL) dan Laser Doppler (Kuzmina et al, 2005, Robinson et al, 2002 dan Stoecker et al, 2009).

Kecurigaan awal KSB adalah melalui anamnesis dan pemeriksaan fisik. Sehingga diagnosis secara klinis merupakan cara deteksi yang penting, oleh karena itu diperlukan kriteriakriteria spesifik yang dapat membantu tegaknya diagnosis secara klinis. Pada penelitian ini, dicoba untuk mengetahui gejala klinis yang sering kali muncul pada kasus KSB sehingga dapat digunakan sebagai prediktor pada KSB.

\section{METODE PENELITIAN}

Sepuluh pasien baru dengan tumor kulit yang berobat ke poliklinik kulit dan kelamin RS Dr. Moewardi diikutkan dalam penelitian deskriptif ini. Diagnosa secara klinis menggunakan tanda-tanda klinis yang sering dijumpai menurut Keratinocyte carcinoma dalam A cancer Journal For Clinicians tahun 2011 yaitu translucent appearance, Teleangiektasi, tepi meninggi, eritema dengan perdarahan, pigmentasi, dan scarlike appearance (Albert and Weinstock, 2011). Setiap pasien diperiksa serial oleh 3 dokter yang berbeda (Interobserver). Pemeriksaan histopatologis dikerjaan sebagai gold standar dan hasilnya dibaca oleh ahli histopatologi.

Tabel 1. Kriteria Diagnosis Klinis

\begin{tabular}{lll}
\hline Translusensi & $:$ & Tampak transparan seperti lilin / mutiara \\
Teleangiektasi & $:$ & Pembuluh darah kapiler yang tampak ireguler, tersebar dan berkelok-kelok \\
Raised border & $:$ & Tepi lebih tinggi daripada bagian tengah \\
Eritem dengan erosi & $:$ & Perubahan warna kulit menjadi kemerahan disertai diskontinuitas epidermis tanpa riwayat trauma \\
Pigmentasi & $:$ & Berwarna hitam atau coklat, berbintik-bintik maupun homogen \\
Scarlike appearance & $:$ & Lesi kulit tampak seperti skar \\
\hline
\end{tabular}

\section{HASIL DAN PEMBAHASAN}

Penelitian ini melibatkan 10 subjek, 6 perempuan dan 4 laki-laki dimana sebanyak 9 orang memiliki lesi di bagian wajah antara lain hidung, pipi, dan dahi serta 1 orang di leher. Seluruhnya dilakukan pemeriksaan secara klinis dan dikonfirmasi dengan hasil histopatologis. Hasil dari diagnosa secara klinis ditemukan pigmentasi pada semua subjek. Teleangiektasi, Raised Border, dan eritema dengan erosi ditemukan pada 9 subjek. Gambaran translusensi hanya ditemukan pada 6 orang. Sedangkan scarlike appearance tidak ditemukan pada semua subjek.

Pemeriksaan histopatologis dilakukan sebagai gold standard pemeriksaan. Ekspertisi hasil dilakukan oleh spesialis patologi anatomi dengan hasil seluruh subjek memiliki gambaran histopatologis yang sesuai dengan KSB.

Tabel 2. Frekuensi kemunculan gejala klinis

\begin{tabular}{ccc}
\hline Kriteria Klinis & Jumlah & Prosentasi \\
\hline Translusensi & 6 & $60 \%$ \\
Teleangiektasi & 9 & $90 \%$ \\
Raised border & 9 & $90 \%$ \\
Eritem dengan erosi & 9 & $90 \%$ \\
Pigmentasi & 10 & $100 \%$ \\
Scarlike appearance & - & - \\
\hline
\end{tabular}

Karsinoma sel basal merupakan tumor ganas yang jarang sekali bermetastase, terdiri dari sel yang mirip dengan sel pada bagian basal epidermis (Mackie et al, 2004). Jika tidak segera diterapi, karsinoma sel basal akan menyebar secara lokal, menghasilkan kerusakan jaringan substansial yang menyebabkan gangguan fungsi dan kosmetik (Carucci et al, 2008).

Karsinoma sel basal lebih sering dijumpai pada orang kulit putih daripada kulit berwarna dan paparan sinar matahari yang lama dan kuat berperan dalam perkembangannya. KSB biasanya muncul setelah usia lebih dari 40 tahun, walaupun dapat juga dijumpai pada anak dan remaja walaupun jarang.

Predileksi kanker ini adalah daerah muka yang terpajan sinar matahari. Daerah yang paling sering terkena adalah sudut bibir dan dahi. Dari penelitian yang dilakukan di Indonesia ternyata terdapat predileksi sebagai berikut : pipi dan dahi $50 \%$, Hidung dan lipatan hidung $28 \%$, Mata dan Sekitarnya 17\%, bibir $5 \%$ (Arnold et al, 2000 and Habib, 1996). Hal ini sesuai dengan penelitian diatas dimana $90 \%$ subjek memiliki lesi di daerah wajah.

Beberapa peneliti mengatakan bahwa terjadinya KSB merupakan gabungan pengaruh sinar matahari, tipe kulit, warna kulit dan 
faktor predisposisi lainnya. Peningkatan radiasi sinar ultraviolet dapat menginduksi terjadinya keganasan kulit pada manusia melalui efek imunologik dan efek karsinogenik. Transformasi sel menjadi ganas akibat radiasi diperkirakan berhubungan dengan terjadinya perubahan pada DNA yaitu terbentuknya photo product yang disebut dimer pirimidin yang diduga berrperan dalam pembentukan tumor. Reaksi sinar ultraviolet menyebabkan efek terhadap proses karsinogenik pada kulit antara lain induksi timbulnya sel kanker, menghambat immunosurveillance dengan menginduksi limfosit $\mathrm{T}$ spesifik untuk tumor tertentu (Carucci et al, 2008 dan Jayanta et al, 2000).

Karsinoma sel basal pada umumnya mudah didiagnosis secara klinis. Meskipun pemeriksaan secara klinis adalah yang paling mudah dikerjakan dan digunakan, ketelitian dan ketepatan pemeriksaan klinis sering tidak diketahui. Ketepatan dalam pemeriksaan klinis dapat didiskripsikan pada inter dan intra observer. Ketepatan perkiraan harus dihasilkan dengan cara blinding, tetapi lesi berubah seiring perbedaan waktu sehingga intraobserver harus dievaluasi dari gambar dari lesi kulit dinilai pada dua waktu yang berbeda. Pada penelitian sebelumnya tentang akurasi diagnostik klinis diperoleh hasil $3 \%$ dari lesi yang dinilai jinak terbukti ganas dan $40 \%$ dari yang diduga keganasan adalah jinak. Dalam penelitian mengenai sensitivitas secara keseluruhan untuk diagnosis klinis Non Melanoma Skin Cancer (NMSC) adalah 56\% sampai 90\%, dan spesifisitas $75 \%$ sampai $90 \%$, dengan nilai tertinggi untuk diagnosis KSB (Mogensen et al, 2007).

Lesi pada KSB terdiri dari satu atau beberapa nodul kecil seperti lilin, semitranslusen berbentuk bundar dengan bagian tengah lesi cekung dan bisa mengalami ulserasi dan perdarahan. Sedangkan tepi meninggi dengan gambaran seperti mutiara merupakan tanda khas pada tumor ini. Pada lesi kulit sering dijumpai tanda-tanda kerusakan seperti teleangiektasi dan atrofi. Hal ini sesuai dengan penelitian diatas dimana sebagian besar gejala klinis muncul pada semua individu seperti teleangiektasi, tepi meninggi, pigmentasi dan eritem yang disertai erosi (Carucci et al, 2008 dan Jayanta et al, 2000).

Pada penelitian oleh Goldberg, Pigmen melanin dapat ditemukan secara histopatologi pada sebanyak $30 \%$ kasus KSB. KSB tipe pigmented lebih sering ditemukan pada orangorang berkulit gelap. Secara klinis, warna biruhitam pada karsinoma sel basal adalah pigmen yang luas dalam tumor dan pada lokasi melanin pada kulit serta efek tyndal. Pigmentasi dapat membantu diagnosa ke arah KSB (Goldberg et al, 2004). Pada penelitian ini, gambaran pigmentasi ditemukan pada seluruh subjek.

Gambaran klinis translusensi, jelly-like appearance yang sering ditemukan pada KSB dengan mata telanjang, berguna untuk untuk membantu diagnosa KSB. Pada penelitian Stocker menunjukkan bahwa gambaran translusensi dapat membantu deteksi awal KSB dengan angka akurasi yang tinggi. Sedangkan pada penelitian ini gambaran translusensi hanya didapatkan pad $70 \%$ subjek. Hal ini mungkin dikarenakan translusensi lebih mudah dilihat pada tahap awal $\mathrm{KSB}$, sedangkan subjek yang diteliti bervariasi lama perjalanan klinisnya (Stoecker et al, 2009). Pada subjek, sebanyak 6 subjek menunjukkan gambaran translusensi.

Sifat-sifat histopatologis pada KSB sangat bervariasi tetapi pada umumnya mempunyai inti yang besar, oval atau memanjang dengan sedikit sitoplasma. Sel pada KSB mirip dengan sel basal pada stratum basal epidermis hanya rasio antara inti dan sitoplasma lebih besar atau tidak tampak adanya jembatan antar sel. Inti dari sel KSB lebih seragam dan tidak tampak gambaran anaplastik (Lever, 1983).

Berbagai teknologi diagnostik yang luas banyak tersedia untuk diagnosis noninvasif dari NMSC. Standar acuan berupa biopsi kulit dan penilaian histopatologi bagaimanapun tidak / belum tergantikan. kriteria klinis dari Keratinocyte carcinoma dalam A cancer Journal For Clinicians tahun 2011 dapat digunakan untuk menegakkan diagnosis secara klinis, walaupun masih harus diuji sensitivitas serta spesivisitasnya. Banyak teknologi yang menawarkan akurasi penegakan diagnosa KSB, terutama sebagai suplemen untuk diagnosis klinis. Untuk itu berbagai tes diagnostik klinis masih memerlukan penelitian yang lebih besar dan independen.

\section{DAFTAR PUSTAKA}

Carucci JA, Leffell DJ. Basal cell carcinoma, Dalam : Freedberg IM, Elsesn AZ, Wolff K, Austen KF, Goldsmith LA, Katz S, Fitzpatrick's 
Dermatology In General Medicine, 7th ed, New York, McGrawHill. 2008;2029-35

Bakis S, Irwig L, Wood G, Wong D. Exfoliative cytology as a diagnostic test for basal cell carcinoma: a meta-analysis, British Journal of Dermatology, 2004, $150: 829-36$.

Tilli CMLJ, Steensel MAM, Krekels GAM. Molecular aetiology and pathogenesis of basal cell carcinoma, British Journal of Dermatology, 2005, 152: 1108-24

Christenson LJ, Borrowman TA, Vachen CM, Tollefson MM, Otley CC, Weaver AL, Roenigk RK, Incidence of basal aell and squamous cell carsinomas in a population younger than 40 years, JAMA, 2005, $294: 681-90$

Solano JG, Rojo BG, sanchez C, Romero MS, Guilermo MP, Basal cell carcinoma : cytologic and immunocytochemical findings in fine-needle aspirates, Diagnostic Cytopathology, Vol 18 : 403-8

Altamura D, Menzies SW, Argenziano G, Zalaudek I, Soyer HP, Sera F, Avramidis M, Deambrosis K, Fargnoli MC, Peris K. Dermatoscopy of basal cell carcinoma : Morphologic variability of global and local features and accuracy of diagnosis, Journal American Academy of Dermatology, 2010, $62: 67$ 75

Kuzmina N, Talme T, Lapins J, Emtestam L, Noninvasive preoperative assessment of basal Cell carcinoma of nodular and superficial types. Skin Research and Technology, 2005, $11: 196-200$

Robinson JK, Fisher SG, Turrisi RJ, Predictors of skin self-examination performance. Cancer, $2002,95: 135-146$
Stoecker WV, Gupta K, Shrestha B, Wronkiewieckz, Chowdhury R, stanley RJ, Jin $\mathrm{Xu}$, Moss RH, Celebi ME, Rabinovitz HS, Oliviero M, Malters, JM, Kolm I, Detection of Basal Cell Carsinoma Using Color and Histogram Measure of Semitranslucent Areas, Skin Research and Technology, 2009, $15: 283-$ 87

Albert MR. and Weinstock MA, Keratinocyte Carcinoma, CA a Cancer Journal for Clinician, 2011, 53 : 292-302

Mackie RM, Quinn AG, Basal Cell Carcinoma, Dalam : Burns T, Breathnach S, Christopher G, Rook's Text Book Of Dermatology, 7th, Blackwell Publishing, 2004, 36.19

Arnold HL, et al, Andrew's disease of The Skin, 9th ed, WB Sauders co, 2000, 820 - 829

Habib TB, Clinical dermatology, 3rd ed, Mosty Missaouri, 1996, 649 - 59

Jayanta K, Widjaya HR, et al. Penanganan karsinoma sel basal dalam : Perkembangan onkologi dan bedah kulit di Indonesia. Kumpulan Makalah Lengkap PIT V Perdoski. Semarang. 2000

Mogensen M, Gregor BE, Jemec. Diagnosis of Nonmelanoma Skin Cancer/Keratinocyte Carcinoma: A Review of Diagnostic Accuracy of Nonmelanoma Skin Cancer Diagnostic Tests and Technologies. Dermatology Surgery. 2007 ; 33:1158-74

Goldberg LH, Friedman RH, Silapunt S, Pigmented speckling as a Sign of Basal Cell Carcinoma, Dermatology Surgery, 2004, 30 : 1553-55

Lever WF. Histopathology of the skin. 6rd ed. JB Lippincot Company. 1983 : 362-574 